\title{
Building Energy Model Development for Retrofit Homes
}

\section{Final Technical Progress Report}

\author{
D Chasar J Blanchard \\ J Mcllvaine \\ S Widder \\ M Baechler
}

September 2012

Pacific Northwest

NATIONAL LABORATORY

Proudly Operated by Battelle Since 1965 


\section{DISCLAIMER}

This report was prepared as an account of work sponsored by an agency of the United States Government. Neither the United States Government nor any agency thereof, nor Battelle Memorial Institute, nor any of their employees, makes any warranty, express or implied, or assumes any legal liability or responsibility for the accuracy, completeness, or usefulness of any information, apparatus, product, or process diselosed, or represents that its use would not infringe privately owned rights. Reference herein to any specific commercial product, process, or service by trade name, trademark, manufacturer, or otherwise does not necessarily constitute or imply its endorsement, recommendation, or favoring by the United States Government or any agency thereof, or Battelle Memorial Institute. The views and opinions of authors expressed herein do not necessarily state or reflect those of the United States Government or any agency thereof.

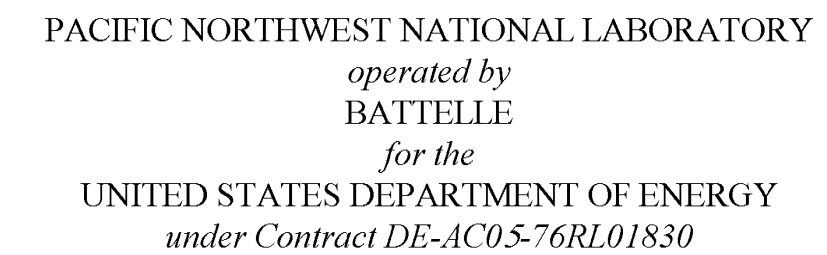

Printed in the United States of America

Available to DOE and DOE contractors from the Office of Scientific and Technical Information,

P.O. Box 62, Oak Ridge, TN 37831-0062;

ph: (865) 576-8401

fax: $(865) 576-5728$

email: reports(a) adonis.osti.gov

\footnotetext{
Available to the public from the National Technical Information Service, U.S. Department of Commerce, 5285 Port Royal Rd., Springfield, VA 22161 ph: (800) 553-6847 fax: $(703) 605-6900$ email: orders@ntis.fedworld.gov online ordering: http://www.ntis.gov/ordering.htm
} 


\title{
Building Energy Model Development for Retrofit Homes
}

\section{Final Technical Progress Report}

\author{
D Chasar ${ }^{1}$ \\ J McIlvaine $^{1}$ \\ J Blanchard $^{2}$
S Widder
M Baechler
}

September 2012

Prepared for

the U.S. Department of Energy

under Contract DE-AC05-76RL01830

Pacific Northwest National Laboratory

Richland, Washington 99352

\footnotetext{
${ }^{1}$ Florida Solar Energy Center. Cocoa, Florida.

${ }^{2}$ Pacific Northwest National Laboratory. Richland, Washington.
} 



\section{Summary}

Based on previous research conducted by Pacific Northwest National Laboratory and Florida Solar Energy Center providing technical assistance to implement 23 deep energy retrofits across the nation, six homes were selected in Florida and Texas for detailed post-retrofit energy modeling to assess realized energy savings (Chandra et al, 2012). Of these homes, three homes in San Antonio were selected for detailed analysis of post-retrofit energy use and realized energy savings. The actual savings achieved in these homes post-retrofit, as determined by a utility bill comparison, is presented.

For the three metered homes in Florida, no pre-retrofit utility bills are available, so a utility bill comparison to determine realized savings is not possible. Assessing realized savings can be difficult for some homes where pre-retrofit occupancy and energy performance are unknown. Initially, savings had been estimated using a HERS Index comparison for these homes. However, this does not account for confounding factors such as occupancy and weather. This research also addresses a method to more reliably assess energy savings achieved in deep energy retrofits for which pre-retrofit utility bills or occupancy information is not available.

A metered home, Riverdale, was selected as a test case for development of a modeling procedure to account for occupancy and weather factors, potentially creating more accurate estimates of energy savings. This "true-up" procedure was developed using Energy Gauge USA software and post-retrofit homeowner information and utility bills. The 11-step process adjusts the post-retrofit modeling results to correlate with post-retrofit utility bills and known occupancy information. The "trued-up" post retrofit model is then used to estimate pre-retrofit energy consumption by changing the building efficiency characteristics to reflect the pre-retrofit condition, but keeping all weather and occupancy-related factors the same. This creates a pre-retrofit model that is more comparable to the post-retrofit energy use profile and can improve energy savings estimates. For this test case, a home for which pre- and post-retrofit utility bills were available was selected for comparison and assessment of the accuracy of the true-up procedure.

Based on the current method, this procedure is quite time intensive. However, streamlined processing spreadsheets or incorporation into existing software tools would improve the efficiency of the process. Retrofit activity appears to be gaining market share, and this method of assessing realized savings in unoccupied homes would be a potentially valuable capability with relevance to marketing, program management, and retrofit success metrics. 



\section{Contents}

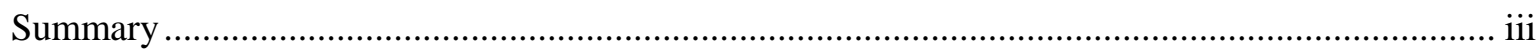

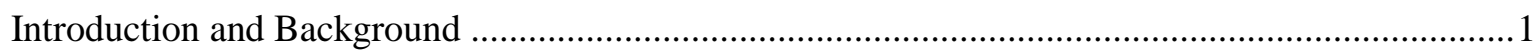

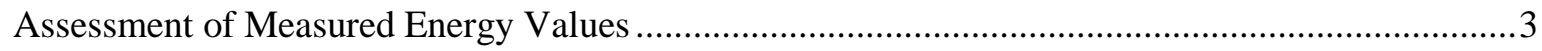

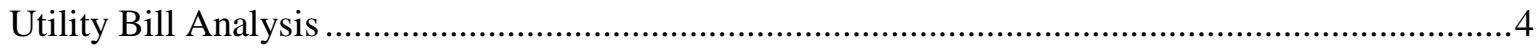

Annual Comparison of Total Electric and Gas Use.........................................................

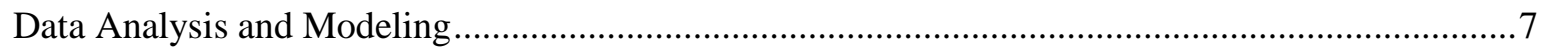

Modeling Retrofit Improvement with Post-retrofit Utility Data ........................................ 7

Step 1: Begin with a Complete HERS Index Rating Model ..........................................

Step 2: Gather One Year of Post-retrofit Utility Bills Including Energy Use and Billing

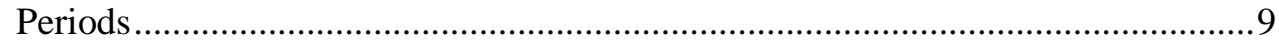

Step 3: Determine Model and Actual HDD and CDD and Ratios ................................ 10

Step 4: Estimate Base Energy Use for Each Fuel from the Post-retrofit Utility Data..... 10

Step 5: Modify the Model to Approximate the Estimated Utility Base Energy Use....... 10

Step 6: Estimate Heating and Cooling Energy Use (Separately) for Each Fuel from Utility Bills........................................................................................................ 13

Step 7: Determine Target Simulated Heating and Cooling Energy Use for Each Fuel... 13

Step 8: Modify Occupancy and Operational Characteristics in Model ............................14

Step 9: Modify Simulated Heating and Cooling Energy Use and Combine with Simulated Base Energy Use ............................................................................. 14

Step 10: Compare Trued-Up Model Whole-House Use to Post-retrofit Utility Bills ....... 15

Step 11: Modify the Trued-Up Model to Reflect Pre-Retrofit Characteristics ................17

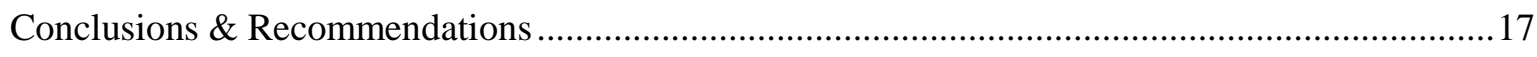

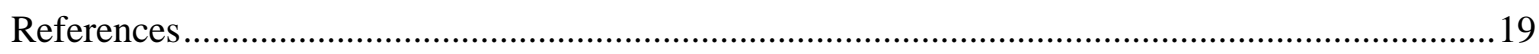





\section{Introduction and Background}

Previously, the Pacific Northwest National Laboratory (PNNL) research team provided technical assistance on approximately 51 selected pilot residences in a variety of climate zones in the Pacific Northwest, Texas, and Florida. The research team, funded by DOE's Building America Program, applied integrated building science and systems engineering principles to determine "what it takes" to achieve energy savings of $30 \%$ to $50 \%$ or more and simultaneously increase the comfort, combustion safety, durability, and indoor air quality (IAQ) of a home (Chandra et al, 2012). Of the 51 homes, 23 homes completed deep energy retrofits within the study timeframe, 15 of which were in the hot humid climate zone. Work on these 15 homes, summarized in Table 1, was led by Florida Solar Energy Center (FSEC). These homes, as well as additional homes for which audits were performed but significant retrofit measures were not completed in time, are described in a previous report (Chandra et al, 2012).

Table 1. Summary of 15 Deep Energy Retrofits in Florida and Texas

\begin{tabular}{|c|c|c|c|c|c|}
\hline Home & & Location & Climate & Retrofits Implemented & $\begin{array}{l}\text { Metering } \\
\text { Approach }\end{array}$ \\
\hline $\begin{array}{l}1980 \text { Single- } \\
\text { Story Home }\end{array}$ & EH-04 & Eustis, FL & $\begin{array}{c}\text { Hot } \\
\text { Humid }\end{array}$ & $\begin{array}{l}\text { SEER } 13 \text { HP, Energy Star windows } \\
\text { and refrigerator, air and duct } \\
\text { sealing, CFLs, R-38 in attic }\end{array}$ & $\begin{array}{c}\text { Electric use, T } \\
\& \mathrm{RH} \\
\text { (installed) }\end{array}$ \\
\hline $\begin{array}{l}1925 \text { Single- } \\
\text { Story Home }\end{array}$ & N/A & Sarasota, FL & $\begin{array}{l}\text { Hot } \\
\text { Humid }\end{array}$ & $\begin{array}{c}\text { Ducts in conditioned space, foamed } \\
\text { sealed attic, R-19 wall insulation, } \\
\text { Low-e windows U/SHGC .35/.21, } \\
\text { 4-ton 18-SEER AC, Tankless gas } \\
\text { water heater, } 82 \% \text { CFLs }\end{array}$ & $\begin{array}{c}\text { Electric use, } \mathrm{T} \\
\text { \& RH } \\
\text { (installed) }\end{array}$ \\
\hline $\begin{array}{l}1979 \text { Single- } \\
\text { Story Home }\end{array}$ & N/A & Venice, FL & $\begin{array}{l}\text { Hot } \\
\text { Humid }\end{array}$ & $\begin{array}{l}\text { Ducts in conditioned space, foamed } \\
\text { sealed attic, R-5.5 board insulation } \\
\text { on walls, Low-e windows U/SHGC } \\
.31 / .24 \text {, 2-ton } 18 \text {-SEER AC, heat } \\
\text { pump water heater, } 100 \% \text { CFLs }\end{array}$ & $\begin{array}{c}\text { Electric use, T } \\
\text { \& RH } \\
\text { (installed) }\end{array}$ \\
\hline $\begin{array}{l}1955 \text { Single- } \\
\text { Story Home }\end{array}$ & Sunglo & $\begin{array}{c}\text { San } \\
\text { Antonio, TX }\end{array}$ & $\begin{array}{l}\text { Hot } \\
\text { Humid }\end{array}$ & $\begin{array}{l}14 \text { SEER AC }+.80 \text { AFUE furnace, } \\
\mathrm{R}-30 \text { roof insulation, } \mathrm{R}-13 \text { wall } \\
\text { insulation, Low-e windows } \\
\text { U/SHGC }-.54 / .30 \& .59100 \% \mathrm{CFL}\end{array}$ & $\begin{array}{l}\text { Electric use, } \mathrm{T} \\
\text { \& RH } \\
\text { (installed) }\end{array}$ \\
\hline $\begin{array}{l}1950 \text { Single- } \\
\text { Story Home }\end{array}$ & $\begin{array}{l}\text { Buena } \\
\text { Vista }\end{array}$ & $\begin{array}{c}\text { San } \\
\text { Antonio, TX }\end{array}$ & $\begin{array}{l}\text { Hot } \\
\text { Humid }\end{array}$ & $\begin{array}{l}\text { 14 SEER AC }+.80 \text { AFUE furnace, } \\
\text { R-30 roof insulation, R-13 wall } \\
\text { insulation, Low-e windows } \\
\text { U/SHGC }-.54 / .30 \& .59,100 \% \text { CFL }\end{array}$ & $\begin{array}{l}\text { Electric use, } \mathrm{T} \\
\quad \& \mathrm{RH} \\
\text { (installed) }\end{array}$ \\
\hline $\begin{array}{l}1949 \text { Single- } \\
\text { Story Home }\end{array}$ & Riverdale & $\begin{array}{c}\text { San } \\
\text { Antonio, TX }\end{array}$ & $\begin{array}{l}\text { Hot } \\
\text { Humid }\end{array}$ & $\begin{array}{l}\text { 14 SEER AC }+.80 \text { AFUE furnace, } \\
\mathrm{R}-30 \text { roof insulation, } \mathrm{R}-13 \text { wall } \\
\text { insulation, Low-e windows } \\
\mathrm{U} / \mathrm{SHGC}-.54 / .30 \& .59,100 \% \mathrm{CFL}\end{array}$ & $\begin{array}{l}\text { Electric use, } \mathrm{T} \\
\text { \& RH } \\
\text { (installed) }\end{array}$ \\
\hline $\begin{array}{l}1960 \text { Single- } \\
\text { Story Home }\end{array}$ & EH-02 & $\begin{array}{l}\text { Lakeland, } \\
\text { FL }\end{array}$ & $\begin{array}{l}\text { Hot } \\
\text { Humid }\end{array}$ & $\begin{array}{l}\text { SEER } 15 \text { HP, low-E windows, air } \\
\text { and duct sealing, CFLs, white roof, } \\
\text { R-30 in attic, R-11 (limited frame } \\
\text { walls), Energy Star ceiling fans }\end{array}$ & $\begin{array}{l}\text { None, utility bill } \\
\text { analysis }\end{array}$ \\
\hline
\end{tabular}




\begin{tabular}{|c|c|c|c|c|c|}
\hline Home & & Location & Climate & Retrofits Implemented & $\begin{array}{l}\text { Metering } \\
\text { Approach }\end{array}$ \\
\hline $\begin{array}{l}2003 \text { Single- } \\
\text { Story Home }\end{array}$ & EH-03 & $\begin{array}{c}\text { Green } \\
\text { Acres, FL }\end{array}$ & $\begin{array}{l}\text { Hot } \\
\text { Humid }\end{array}$ & $\begin{array}{l}\text { Heat pump water heater, Energy } \\
\text { Star refrigerator, CFLs, R-38 attic, } \\
\text { R-11 one frame wall, passive } \\
\text { outside-air ventilation }\end{array}$ & $\begin{array}{l}\text { None, utility bill } \\
\text { analysis }\end{array}$ \\
\hline $\begin{array}{l}1962 \text { Single- } \\
\text { Story Home }\end{array}$ & EH-06 & $\begin{array}{l}\text { Melbourne, } \\
\text { FL }\end{array}$ & $\begin{array}{l}\text { Hot } \\
\text { Humid }\end{array}$ & $\begin{array}{l}\text { SEER } 14 \text { AC (not HP), R-38 partial } \\
\text { attic, Energy Star windows, air and } \\
\text { duct sealing, CFLs, Energy Star } \\
\text { refrigerator }\end{array}$ & $\begin{array}{l}\text { None, utility bill } \\
\text { analysis }\end{array}$ \\
\hline $\begin{array}{l}1964 \text { Single- } \\
\text { Story Home }\end{array}$ & EH-07 & $\begin{array}{l}\text { Melbourne, } \\
\text { FL }\end{array}$ & $\begin{array}{l}\text { Hot } \\
\text { Humid }\end{array}$ & $\begin{array}{c}\text { SEER } 13 \text { AC (not HP), Energy Star } \\
\text { windows and refrigerator, R-38 } \\
\text { Partial attic, air and duct (new) } \\
\text { sealing, CFLs }\end{array}$ & $\begin{array}{l}\text { None, utility bill } \\
\text { analysis }\end{array}$ \\
\hline $\begin{array}{l}1950 \text { Single- } \\
\text { Story Home }\end{array}$ & $\mathrm{EH}-12$ & $\begin{array}{l}\text { Lakeland, } \\
\text { FL }\end{array}$ & $\begin{array}{l}\text { Hot } \\
\text { Humid }\end{array}$ & $\begin{array}{c}\text { SEER } 15 \text { HP and new ducts, air } \\
\text { sealing (still leaky), Energy Star } \\
\text { windows, R-30 attic, Energy Star } \\
\text { ceiling fans, CFLs }\end{array}$ & $\begin{array}{l}\text { None, utility bill } \\
\text { analysis }\end{array}$ \\
\hline $\begin{array}{l}1959 \text { Single- } \\
\text { Story Home }\end{array}$ & EH-14 & $\begin{array}{l}\text { Indian } \\
\text { Harbor } \\
\text { Beach, FL }\end{array}$ & $\begin{array}{l}\text { Hot } \\
\text { Humid }\end{array}$ & $\begin{array}{l}\text { Tankless gas water heater, Energy } \\
\text { Star windows, R-20 foam at roof } \\
\text { deck, air sealing, interior ducts } \\
\text { (unvented attic), CFLs }\end{array}$ & $\begin{array}{l}\text { None, utility bill } \\
\text { analysis }\end{array}$ \\
\hline $\begin{array}{l}2000 \text { Single- } \\
\text { Story Home }\end{array}$ & EH-19 & $\begin{array}{l}\text { West Palm } \\
\text { Beach, FL }\end{array}$ & $\begin{array}{l}\text { Hot } \\
\text { Humid }\end{array}$ & $\begin{array}{l}\text { SEER } 15 \text { AC (not HP), heat pump } \\
\text { water heater, R-38 attic, air and } \\
\text { duct sealing, Energy Star } \\
\text { refrigerator, CFLs, passive outside- } \\
\text { air ventilation }\end{array}$ & $\begin{array}{l}\text { None, utility bill } \\
\text { analysis }\end{array}$ \\
\hline $\begin{array}{l}1996 \text { Two- } \\
\text { Story Home }\end{array}$ & EH-21 & $\begin{array}{c}\text { Lake Worth, } \\
\text { FL }\end{array}$ & $\begin{array}{l}\text { Hot } \\
\text { Humid }\end{array}$ & $\begin{array}{l}\text { SEER } 14.5 \text { AC (not HP), heat } \\
\text { pump water heater, R-38 attic, air } \\
\text { and duct sealing, Energy Star } \\
\text { refrigerator, CFLs }\end{array}$ & $\begin{array}{l}\text { None, utility bill } \\
\text { analysis }\end{array}$ \\
\hline $\begin{array}{l}1997 \text { Single- } \\
\text { Story Home }\end{array}$ & $\mathrm{EH}-22$ & $\begin{array}{c}\text { Lake Worth, } \\
\text { FL }\end{array}$ & $\begin{array}{l}\text { Hot } \\
\text { Humid }\end{array}$ & $\begin{array}{c}\text { SEER 14.5 AC (not HP), heat } \\
\text { pump water heater, Energy Star } \\
\text { windows, R-38 attic, air and duct } \\
\text { sealing, Energy Star refrigerator, } \\
\text { CFLs }\end{array}$ & $\begin{array}{l}\text { None, utility bill } \\
\text { analysis }\end{array}$ \\
\hline
\end{tabular}

From the subset of 15 completed homes in Florida and Texas, six homes were selected for extensive monitoring to investigate achieved energy savings, analyze differences between estimated (modeled) and realized energy savings, assess the impact of behavioral components on expected energy reduction, and report homeowner motivations and feedback in performing deep energy upgrades. In addition, the PNNL research team provided metering support to six ORNL-led deep energy retrofits in Atlanta, which are being reported on separately (Jackson et al, 2012). 
Of the metered homes in Florida and Texas, three homes in San Antonio, Texas, were selected for detailed analysis of post-retrofit energy use and realized energy savings. The actual savings achieved in these homes post-retrofit, as determined by a utility bill comparison, is presented. For the three metered homes in Florida, no pre-retrofit utility bills are available, so a utility bill comparison to determine realized savings is not possible. As such, a method was developed to more reliably assess energy savings achieved in deep energy retrofits for which pre-retrofit utility bills or occupancy information is not available.

This research project was performed by FSEC for PNNL as a companion project to similar research that is occurring in the Pacific Northwest. This research builds on previous research conducted by PNNL and FSEC providing technical assistance to implement deep energy retrofits across the nation. This report accompanies a similar report, published concurrently, describing research results for seven metered homes in the Pacific Northwest (Blanchard et al, 2012 DRAFT).

\section{Assessment of Measured Energy Values}

Two types of home energy monitors were used to track electric end use in hourly increments at the six retrofit study homes selected for detailed energy monitoring in the hot humid climate. Three of the homes, located in Florida, utilized eMonitors and three homes, located in San Antonio, utilized The Energy Detective (TED). Further details on this monitoring effort can be found in section 2.3 of a previous report describing the technical assistance and retrofit measures for homes participating in this project (Chasar et al, 2012).

The time constraints of this project required focusing only a few homes for detailed analysis of actual versus estimated savings. The three San Antonio homes where energy measurements were collected with TED devices were selected for analysis, since complete data on these homes was readily available, including post-retrofit utility bills which can be difficult and time consuming to obtain. As described in more detail in the earlier report, this device stores data locally and must be downloaded on a periodic basis. Collecting data from TED proved challenging as the devices required periodic resets to maintain continuous data logging, resulting in data collection gaps. One data gap occurred in all three homes due to memory overwrite when the devices were left to log locally for a long period of time. ${ }^{1}$ In one home this interim period was completely lost due to a TED malfunction. In spite of these challenges the collected energy data proved to correlate well with monthly electric utility bills.

Table 2 shows how TED data compared with monthly electric billing in each of the three homes. During most months the deviation between TED and billing data was 3\% or less. This is roughly the error associated with uncertainty in the billing period length which varied from 27 to 34 days. TED energy measurements were matched up to utility bill periods that ran from the day after the previous meter read date to the current meter read date. Most TED readings were within the error bound of at least one full day in the billing period $( \pm 3.7 \%)$. Summing up all bill periods for each home showed an error of no more than $2 \%$ among the three homes.

\footnotetext{
${ }^{1}$ This period occurred between a previous project and the current project when staffing changes caused a gap in contracts between FSEC and PNNL, so no work was able to occur.
} 
Table 2. Comparison of TED Measured Energy with Electric Utility Bill Variation of TED from Billed kWh (Billed kWh / \%)

\begin{tabular}{crrr}
\hline Billing Month & Buena Vista & Riverdale & Sunglo \\
\hline Jul 2011 & N/A & N/A & $1435 / 4 \%$ \\
Aug 2011 & $593 / 3 \%$ & $1471 / 2 \%$ & $1085 /-2 \%$ \\
Sep 2011 & $631 / 1 \%$ & $1910 /-1 \%$ & $1061 / 0 \%$ \\
Oct 2011 & $369 / 1 \%$ & $1112 / 2 \%$ & $701 /-5 \%$ \\
Nov 2011 & $170 / 1 \%$ & $821 / 6 \%$ & $426 /-5 \%$ \\
Dec 2011 & $151 / 5 \%$ & $657 /-2 \%$ & \\
Jan 2011 & $250 / 3 \%$ & N/A & \\
Feb 2012 & $166 / 3 \%$ & N/A & \\
Mar 2012 & N/A & N/A & \\
Apr 2012 & N/A & N/A & $615 / 1 \%$ \\
May 2012 & N/A & $907 / 1 \%$ \\
Jun 2012 & N/A & $898 / 1 \%$ \\
Jul 2012 & $251 / 4 \%$ & N/A & $998 / 1 \%$ \\
Aug 2012 & $418 / 3 \%$ & $5971 / 1 \%$ & $8123 / 0 \%$ \\
Full Period & $376 / 5 \%$ & &
\end{tabular}

\section{Utility Bill Analysis}

\section{Annual Comparison of Total Electric and Gas Use}

Table 3 shows a comparison of pre- and post-retrofit utility bills for one-year periods from June of one year to May of the following year. This choice of study period allowed direct comparison of 12 utility bills for three different "years" from 2008 to 2012.

Post-retrofit electric energy savings varied widely among the homes. The greatest electric savings were seen at the Buena Vista home, which is the only home with pre-retrofit central air conditioning (AC). The other homes presented a challenge in comparing pre/post retrofit electric use as window AC units with their inherent zoning ability were used for cooling. The billed post-retrofit electric savings ranged on average from $28 \%$ at Buena Vista to $20 \%$ at Sunglo and $5 \%$ at Riverdale.

Gas savings also varied widely among the homes. Unconventional pre-retrofit space heating approaches in Riverdale and Sungalo may have confounded the savings assessment. Specifically, neither of these homes had a central heating system. In addition, the occupant survey at Riverdale revealed the use of the oven for home heating, which may explain some of the large gas savings (44\% on average). Sunglo, on the other hand, showed a post-retrofit increase in gas use of $43 \%$, which may be partially attributed to the use of a window-mounted heat pump unit for space heating. The likely effect of this scenario would be greater electric use and lower gas use in heating months than the Riverdale home which was supported by the billing data. The Buena Vista home showed only a modest gas savings of $14 \%$ on average. 
Table 3. Pre/Post Retrofit Comparison of Annual Gas and Electric Bills

\begin{tabular}{|c|c|c|c|c|c|c|c|}
\hline \multirow[b]{2}{*}{ Year } & \multicolumn{2}{|c|}{ Buena Vista } & \multicolumn{2}{|c|}{ Riverdale } & \multicolumn{2}{|c|}{ Sunglo } & \multirow{2}{*}{$\begin{array}{c}\text { Heating } \\
\text { Degree } \\
\text { Days }\end{array}$} \\
\hline & $\begin{array}{l}\text { Electric } \\
(\mathrm{kWh})\end{array}$ & Gas (CCF) & $\begin{array}{c}\text { Electric } \\
(\mathrm{kWh})\end{array}$ & $\begin{array}{l}\text { Gas } \\
(\mathrm{CCF})\end{array}$ & $\begin{array}{c}\text { Electric } \\
(\mathrm{kWh})\end{array}$ & Gas (CCF) & \\
\hline $\begin{array}{l}\text { June } 2008 \text { - } \\
\text { May } 2009\end{array}$ & 4743 & 224 & 11599 & 446 & 11396 & 172 & 1057 \\
\hline $\begin{array}{l}\text { June } 2009 \text { - } \\
\text { May2010 }\end{array}$ & 6054 & 308 & 13219 & 541 & 9307 & 182 & 1798 \\
\hline $\begin{array}{l}\text { Pre-retrofit } \\
\text { Average }\end{array}$ & 5398 & 266 & 12409 & 494 & 10352 & 177 & 1428 \\
\hline $\begin{array}{c}\text { June } 2011 \text { - May } \\
2012\end{array}$ & 3901 & 230 & 11763 & 276 & 8260 & 253 & 1130 \\
\hline $\begin{array}{c}\text { Savings wrt 2008- } \\
2009\end{array}$ & $17.8 \%$ & $-2.5 \%$ & $-1.4 \%$ & $38.2 \%$ & $27.5 \%$ & $-46.9 \%$ & $-6.9 \%$ \\
\hline $\begin{array}{c}\text { Savings wrt 2009- } \\
2010\end{array}$ & $35.6 \%$ & $25.4 \%$ & $11.0 \%$ & $49.0 \%$ & $11.2 \%$ & $-39.2 \%$ & $37.2 \%$ \\
\hline $\begin{array}{l}\text { Savings wrt } \\
\text { Average }\end{array}$ & $27.7 \%$ & $13.7 \%$ & $5.2 \%$ & $44.1 \%$ & $20.2 \%$ & $-42.9 \%$ & $20.8 \%$ \\
\hline
\end{tabular}

Cooling energy analysis was performed on the three San Antonio retrofit homes using 5 years of utility bills ( 3 pre-retrofit and 2 post-retrofit). Base electric loads that represent the non-HVAC component of the monthly bill were estimated as the average energy $(\mathrm{kWh})$ from the three lowest bills in each home. This base load was then subtracted from the energy billed during each of the 4 months from June through September to derive estimated cooling energy use for the summer billing periods. This provided 12 pre-retrofit data points and seven post-retrofit data points. Only three bills from 2012 (June, July and August) were available for this report.

Figure 1 shows linear regression plots of cooling energy versus cooling degree-days (CDD) for the five summer billing cycles. The plots show a reasonably strong correlation in two of the three San Antonio homes with estimated savings of $63 \%$ at the Buena Vista home and $40 \%$ at the Riverdale home. Data for the Sunglo home showed a much poorer correlation for both the pre- and post-retrofit data and estimated savings were much lower (7\%). The Sunglo home was found to have substantial duct leakage which was repaired after the first 2 months of data monitoring thus only five of seven data points were used for the post-retrofit analysis. The poor correlation of the Sunglo data may be partially attributed to the air source, window-mounted, heat pump unit known to be used there for winter-time heating. This would artificially raise the base load and skew the pre-retrofit data points. This is borne out in Figure 1 by the low coefficient of determination $\left(\mathrm{R}^{2}=0.22\right)$ for the regression line. This expression of "goodness of fit" was much improved in the post-retrofit regression $\left(\mathrm{R}^{2}=0.60\right)$. 


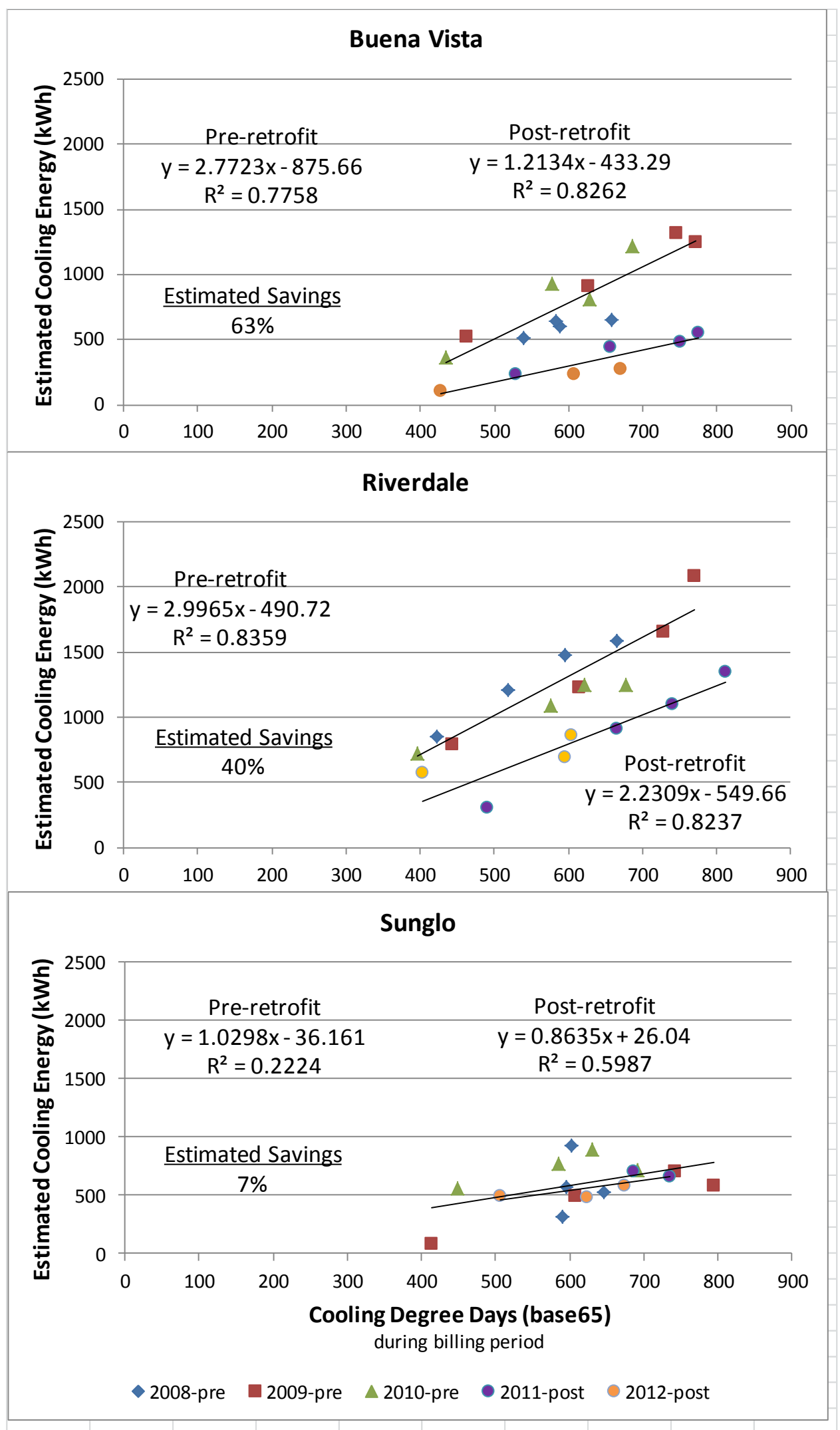

Figure 1. Utility Bill Analysis of Cooling Energy 


\section{Data Analysis and Modeling}

Initial work was performed in July establishing the ability for EnergyGauge USA (EG USA), an hourly energy use simulation software, to perform hourly simulations with actual meteorological year (AMY) data. EG USA normally uses typical meteorological year (TMY3) data, which is representative of "average" weather for a specific location. AMY files in the same format as TMY3 files were obtained from Weather Analytics and were successfully incorporated into an EG USA annual building simulation.

Initial simulations showed an unusually high increase in cooling energy use with respect to the TMY simulations as shown in Table 4. A review of cooling-related input parameters (CDD and solar irradiance) in the AMY and TMY weather files showed the potential for increased cooling requirements, but not of the magnitude seen in the simulation results. After working with Weather Analytics and EG USA software developers on this issue, it was determined that the AMY files have known errors in solar irradiance readings that are artificially high primarily during times of high humidity. Weather Analytics is working on a correction factor to improve the accuracy of the solar irradiance values of the weather file. Modified files should be available in the coming months (contact: Chuck Khuen).

Table 4. Comparison of AMY and TMY Weather File Inputs and EG USA Outputs

\begin{tabular}{cccccc}
\hline Parameter & Type & TMY & $\begin{array}{c}\text { AMY 2011 } \\
(\text { KSKF) }\end{array}$ & $\begin{array}{c}\text { AMY 2011- } \\
12(\text { KSKF })\end{array}$ & $\begin{array}{c}\text { AMY 2011 } \\
(\text { KSSF })\end{array}$ \\
\hline Cooling Degree-Days & Weather & 3103 & $4014(+29 \%)$ & $3703(+19 \%)$ & $4326(+39 \%)$ \\
Direct Normal Irradiance $\left(\mathrm{W} / \mathrm{m}^{2}\right)$ & Weather & 186 & $232(+25 \%)$ & $224(+20 \%)$ & $228(+22 \%)$ \\
Global Horizontal Irradiance $\left(\mathrm{W} / \mathrm{m}^{2}\right)$ & Weather & 205 & $218(+6 \%)$ & $218(+6 \%)$ & $218(+6 \%)$ \\
EG USA Cooling Energy $(\mathrm{kWh})$ & $\begin{array}{c}\text { Simulation } \\
\text { Output }\end{array}$ & \multirow{2}{*}{1373} & $2880(+110 \%)$ & $2495(+82 \%)$ & $\begin{array}{c}3164 \\
(+130 \%)\end{array}$ \\
\hline
\end{tabular}

\section{Modeling Retrofit Improvement with Post-retrofit Utility Data}

For all the homes supported by FSEC in the PNNL retrofit field study (2010-12), projected savings were calculated using EG USA. The homes were rated using the Home Energy Rating Systems (HERS) Index, and the projected energy savings were calculated using the "Annual Simulation" calculation. The majority of homes supported by FSEC during the field study were unoccupied at the time of retrofit with no pre-retrofit utility data for comparison to the post-retrofit period. An alternative method of assessing realized savings is needed for this type of retrofit at the time of sale or other major transition in occupancy, since pre- and post-retrofit utility bills cannot be compared.

The original savings projections from comparison of pre- and post-retrofit HERS Index reflect standardized, rather than actual occupancy, weather, and operating conditions in accordance with HERS Index calculation procedures (RESNET, 2006). A modified post-retrofit model that reflects actual occupancy, weather and operational conditions can produce a closer, truer match with actual post-retrofit utility data. Further modifying the "trued-up" post-retrofit model with pre-retrofit building characteristics can create a simulated pre-retrofit condition that more accurately reflects the weather and occupancy of the new occupants. This enables a new pre-post comparison to be made. Researchers from FSEC, PNNL, Calcs-Plus, and Oak Ridge National Laboratory have collaborated and hypothesize that this would 
represent savings under actual conditions more accurately than a HERS Index comparison under standardized conditions. To investigate, FSEC researchers tested the procedure using the Riverdale house. This allowed the trued-up modeled energy savings to be compared to the measured and utility bill savings discussed in the previous section to determine the accuracy of the procedure.

The weather is a major factor influencing both heating and cooling energy use as well as variation from year to year. Accounting for weather differences between the modeled and actual energy use is a significant challenge. As described in the previous section, researchers attempted unsuccessfully to substitute AMY data for the TMY3 data normally used in EG USA. Instead of the weather file substitution, researchers accounted for weather in post-processing of simulation output. Simulated monthly heating and cooling energy use were each modified by a ratio of typical (TMY3) to actual heating degree-days (HDD) or cooling degree-days (CDD) respectively. The complete true-up procedure is described as Step 1 through 11 below.

Occupancy and operational characteristics can also be modified within the model. However, regardless of these modifications, the HERS Index will remain constant because standardized versions of these will still be imbedded in the HERS calculation procedure. Therefore, these true-up calculations should be produced using the "Annual Simulation" option in EG USA or similar monthly energy use calculation option in other software that considers user input settings rather than standardized HERS settings.

The difference between this comparison and the HERS Index comparison is that this one reflects savings for the retrofit package under the actual occupancy, operation, and weather conditions. There are a few other calculation nuances involved in the HERS procedure related to fuel neutralization, ventilation, and possibly others.

There is a high level of uncertainty inherent in the following procedure. However, this proposed method of projecting, or actually retro-jecting, what the savings from a deep retrofit would have been under the same weather, occupancy, and operational conditions as the post-retrofit period for which utility consumption is known is anticipated to produce more accurate results than a traditional HERS comparison based on building component changes alone. The true-up procedure described below makes use of only those resources that would be available for an unoccupied deep retrofit with no pre-retrofit utility records. These are outlined in Steps 1-4, 6, and 7. The procedure involves modifying a postretrofit simulation model to mimic post-retrofit utility bills based on actual weather and occupancy (Steps 5 and, 8-10), then reverting the model back to pre-retrofit characteristics (Step 11) for a pre-post comparison. Using the Riverdale home allows a comparison of results from this procedure to actual utility bill analysis for the same house, to assess the method's accuracy.

\section{Step 1: Begin with a Complete HERS Index Rating Model}

For the Riverdale home, the HERS Index rating before and after retrofit were 163 and 92 respectively representing a whole house improvement of $43 \%$ from equipment and envelope retrofits (Table 5). 
Table 5. Riverdale House Pre- and Post-Retrofit Characteristics and Improvements

\begin{tabular}{|c|c|c|}
\hline & Pre-retrofit & Post-retrofit \\
\hline Roof & $\begin{array}{l}\text { Near flat, uninsulated roof with medium } \\
\text { color, built up gravel finish }\end{array}$ & $\begin{array}{l}\text { New } 4 / 12 \text { pitch roof, dark shingles with radiant } \\
\text { barrier backed decking, and R-30 attic insulation }\end{array}$ \\
\hline Walls & Frame with R-7 insulation & R-13 total insulation \\
\hline Windows & Single pane, clear & Double pane, U-value 0.54 , SHGC 0.30 \\
\hline Infiltration & $\mathrm{ACH} 50=22.33$ & $\mathrm{ACH} 50=4.23$ \\
\hline Heating System & Unvented, gas space heater, $\mathrm{COP}=1 *$ & Forced air gas furnace 0.80 AFUE \\
\hline Cooling System & $\begin{array}{l}3 \text { EER window units } \\
\text { Approx. } 2 \text { ton total capacity }\end{array}$ & 2 ton, forced air central AC, SEER 14 \\
\hline Ducts & No ducts & $\begin{array}{l}\text { R-6 duct system with attic mounted air handler and } \\
\text { passive outside air ventilation system } \\
\text { CFM25out }=45(\text { qn }, \text { out }=0.043) \\
\text { CFM25tot }=50(\text { qn,tot }=0.048)\end{array}$ \\
\hline Water Heater & 40 gal, natural gas, $\mathrm{EF}=$ approx. 0.5 & 40 gal, natural gas, $\mathrm{EF}=0.62$ \\
\hline
\end{tabular}

\section{Step 2: Gather One Year of Post-retrofit Utility Bills Including Energy Use and Billing Periods}

The Riverdale retrofit was completed in the summer of 2011. Utility bills for August 2011 through July 2012 were used for this exercise (Table 6). The utility involved provides both gas and electricity and reads the meters for both at the same time, producing identical billing periods for both fuels.

Table 6 also shows the AMY HDD and CDD. Note that HDD were highest between November and March and CDDs were highest between April and October. Gas and electricity use followed the same pattern presumably reflecting the use of heating and cooling respectively. These intervals were chosen as the heating and cooling season with respect to the simulation models.

For this effort, researchers chose to work with calendar months when developing HDD and CDD data. This saves time in the total effort because they can be used with the monthly simulation output. The timing of the utility billing period plays a factor in developing the weather correction ratios that are used to improve match between the model and utility data. If the read dates had been significantly closer to the middle of the month, additional steps would be required to calculate the HDD and CDD ratios. Instead of working with the direct monthly (calendar) output from EG USA, we would need to consolidate the EG USA hourly output to correspond to the utility billing periods (e.g. July 15 - August 14 , rather than the calendar month of July). However, this was not a factor in the analysis for this particular house, since the read dates are very close to the beginning of each month and very similar for both electric and gas in the Riverdale home, as shown in Table 6.

Table 6. Energy Consumption from Post-retrofit Year from Gas and Electric Utility Bills

\begin{tabular}{|c|c|c|c|c|c|c|c|c|c|c|c|c|c|c|}
\hline & Units & Jan & Feb & Mar & April & May & June & July & Aug & Sept & Oct & Nov & Dec & Annual \\
\hline Read Date & & 40945 & 40974 & 41005 & 41036 & 41066 & 41095 & 41124 & 40793 & 40822 & 40854 & 40882 & 40926 & \\
\hline Billing Period & Days & 29 & 31 & 31 & 32 & 30 & 29 & 29 & 34 & 29 & 30 & 31 & 31 & 366 \\
\hline Electric Use: & kWh & 514 & 541 & 714 & 1003 & 1128 & 1250 & 1418 & 1910 & 1112 & 821 & 657 & 627 & 11695 \\
\hline \multirow[t]{3}{*}{ Gas Use: } & Therm & 43 & 39 & 31 & 11 & 10 & 5 & 8 & 12 & 10 & 12 & 44 & 45 & 270 \\
\hline & CDD & 20 & 31 & 137 & 286 & 393 & 573 & 578 & 748 & 542 & 252 & 116 & 24 & 3700 \\
\hline & HDD & 339 & 275 & 113 & 25 & 5 & 0 & 0 & 0 & 4 & 63 & 196 & 403 & 1422 \\
\hline
\end{tabular}

Note: Red cells indicate summer/cooling months; blue cells indicate winter/heating months. 


\section{Step 3: Determine Model and Actual HDD and CDD and Ratios}

Next, ratios comparing the TMY CDD and HDD to the actual HDD and CDD observed during the billing period are calculated. EG USA uses TMY3 weather data for simulations. TMY3 and AMY HDD and CDD for San Antonio are shown in Table 7. The AMY data was acquired at no charge from weatherunderground.com. Ratios A and B are used to relate modeled and actual heating and cooling energy use in later steps. Note that the ratios have only been calculated for the months in which we have addressed heating and cooling energy use, highlighted in blue and red respectively.

Table 7. HDD, CDD, and Ratios A and B for Actual Weather (AMY) and Typical Weather Used in Simulations (TMY3)

\begin{tabular}{|c|c|c|c|c|c|c|c|c|c|c|c|c|c|}
\hline AMY Year & 2012 & 2012 & 2012 & 2012 & 2012 & 2012 & 2012 & 2011 & 2011 & 2011 & 2011 & 2011 & \\
\hline Month & Jan & Feb & Mar & Apr & May & Jun & Jul & Aug & Sep & Oct & Nov & Dec & Total \\
\hline \multicolumn{14}{|c|}{ Simulation Weather (TMY3) } \\
\hline TMY3 CCD & 12 & 26 & 91 & 157 & 323 & 552 & 564 & 601 & 411 & 235 & 100 & 30 & 3103 \\
\hline TMY3 HDD & 472 & 352 & 197 & 53 & 13 & 0 & 0 & 0 & 14 & 47 & 198 & 405 & 1751 \\
\hline \multicolumn{14}{|l|}{ Actual Weather (AMY) } \\
\hline AMY CDD & 20 & 31 & 137 & 286 & 393 & 573 & 578 & 748 & 542 & 252 & 116 & 24 & 3700 \\
\hline AMY HDD & 339 & 275 & 113 & 25 & 5 & 0 & 0 & 0 & 4 & 63 & 196 & 403 & 1422 \\
\hline \multicolumn{2}{|c|}{ Cooling Degree Day Multipliers } & & & & & & & & & & & & Average \\
\hline Ratio A CDD (TMY3/AMY) & \multirow{2}{*}{\multicolumn{3}{|c|}{$\begin{array}{l}\text { Estimated Limited } \\
\text { Cooling }\end{array}$}} & 0.55 & 0.82 & 0.96 & 0.98 & 0.80 & 0.76 & 0.94 & \multirow{2}{*}{\multicolumn{2}{|c|}{$\begin{array}{l}\text { Est. Limited } \\
\text { Cooling }\end{array}$}} & 0.83 \\
\hline Ratio B CDD (AMY/TMY3) & & & & 1.81 & 1.22 & 1.04 & 1.02 & 1.24 & 1.32 & 1.07 & & & 1.25 \\
\hline Heating Degree Day Multipl & iers & & & & & & & & & & & & Average \\
\hline Ratio A HDD (TMY3/AMY) & 1.39 & 1.28 & 1.74 & \multirow{2}{*}{\multicolumn{7}{|c|}{ Estimated Limited Heating }} & 1.01 & 1.01 & 1.29 \\
\hline Ratio B HDD (AMY/TMY3) & 0.72 & 0.78 & 0.57 & & & & & & & & 0.99 & 0.99 & 0.81 \\
\hline
\end{tabular}

\section{Step 4: Estimate Base Energy Use for Each Fuel from the Post-retrofit Utility Data}

The last preparation step prior to beginning modifications to the model was to estimate the base energy use for the utility data. The base load refers to the total energy use not related to heating or cooling. This is done by averaging the three lowest months' energy use for each fuel. These likely represent months with little to no heating or cooling use, but also it's very likely that they only loosely correspond to actual base energy use. Variation in the base may relate to differences in the number of days in the billing period, occupant absence, equipment failure, or other unusual events, rather than variation in heating/cooling energy use.

For electricity, the months with lowest bills were December, January, and February, with electricity use of 627,514 , and $541 \mathrm{kWh}$, respectively. These months were averaged to arrive at an estimated base of $561 \mathrm{kWh}$ per month or $6,732 \mathrm{kWh}$ annually. Averaging the lowest gas use of 10, 5, and 8 therms from May, June, and July, respectively, produced an estimated base load of 7.7 therms monthly, or 92.4 therms annually.

\section{Step 5: Modify the Model to Approximate the Estimated Utility Base Energy Use}

In step 5, the EG USA model is modified to match, as closely as possible, the base energy consumption from utility bills estimated in step 4. Build San Antonio Green staff have visited this home several times since retrofit and ascertained that no major changes have been made to the house since the retrofit. This was an important step to verify that the equipment and envelope characteristics in the model 
match the actual condition of the house. For example, addition of a second refrigerator or a window AC could have a major impact on utility bills.

The base energy use modeled by EG USA is comprised of all the modeled end uses except heating and cooling. EG USA does not have the capability to input seasonal variations in household operation such as seasonal variation in cooking. Therefore, in the simulation, unlike in real life, the base energy use stays the same across all months. EG USA does model minor variations related to the number of days per month as seen in the appliance and lighting rows of the monthly energy use report in Figure 2 . The base loads can be adjusted, however, by modifying various inputs related to appliance, water heating, and lighting use. Guided by homeowner responses to survey questions, modifications included daily hot water demand, water heater set point, and ceiling fan operation. Additional adjustments were made to non-retrofit appliance efficiencies such that the modeled base energy consumption matched the estimated base energy consumption from the utility bills (from step 4). 


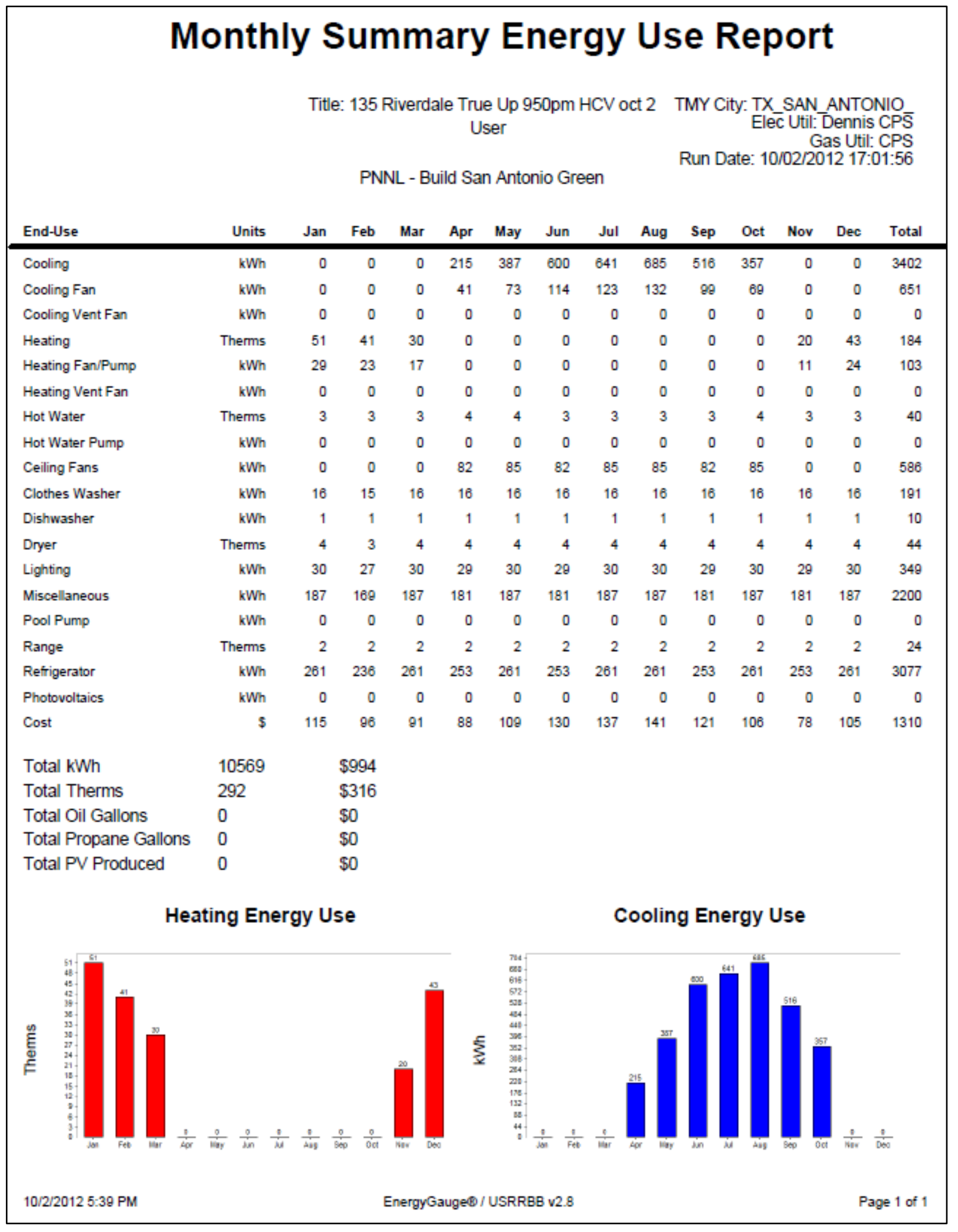

Figure 2. Monthly End Use: EG USA Report of Monthly Energy Consumption by End Use 
The annual base energy use is shown in Table 8 for the HERS rating simulation model, the trued-up model, and the utility data (base estimated). The adjustments to the model brought it significantly closer to the base energy use estimated for the post-retrofit utility.

Table 8. Base Energy Use Calculated from Simulations and Estimated from Post-retrofit Utility Data

\begin{tabular}{|l|c|c|c|}
\hline & HERS Rated Home & Trued-Up Model & Utility Bills \\
\hline Electricity $(\mathrm{kWh})$ & 4,492 & 6,523 & 6,732 \\
\hline Gas (Therms) & 207 & 111 & 92.4 \\
\hline
\end{tabular}

\section{Step 6: Estimate Heating and Cooling Energy Use (Separately) for Each Fuel from Utility Bills}

To estimate the heating and cooling energy use, the estimated utility base energy use determined in Step 5 was subtracted from the total utility energy use for each month for the defined heating (November - March) and cooling (April - October) seasons. Table 9 shows the resulting estimated heating and cooling energy use for the post-retrofit utility data. There is electric fan power associated with the central, forced air natural gas furnace that has not been addressed in this exercise. Although technically part of heating energy use, it cannot be reliably disaggregated from the electric utility data because it is a small load in comparison to total electric, as evidenced from the simulation report in Figure 2 above.

Table 9. Estimated Heating and Cooling Energy Use from Gas and Electric Utility Bill Data Calculated as Actual Utility Bills Minus the Estimated Utility Base Energy Use

\begin{tabular}{|r|c|c|c|c|c|c|c|c|c|c|c|c|c|c|}
\hline & Units & Jan & Feb & March & April & May & June & July & Aug & Sept & Oct & Nov & Dec & Annual \\
\hline Util Gas Total & Therms & 43 & 39 & 31 & 11 & 10 & 5 & 8 & 12 & 10 & 12 & 44 & 45 & 270 \\
\hline Util Gas Base & Therms & 7.7 & 7.7 & 7.7 & 7.7 & 7.7 & 7.7 & 7.7 & 7.7 & 7.7 & 7.7 & 7.7 & 7.7 & 92.40 \\
\hline $\begin{array}{r}\text { Estimated Util Gas } \\
\text { Heating Use }\end{array}$ & Therms & 35.3 & 31.3 & 23.3 & \multicolumn{7}{|c|}{ Estimated Limited Heating } & 36.3 & 37.3 & 163.5 \\
\hline $\begin{array}{r}\text { Util Electric Total } \\
\text { Util Electric Base }\end{array}$ & $\mathrm{kWh}$ & 514 & 541 & 714 & 1003 & 1128 & 1250 & 1418 & 1910 & 1112 & 821 & 657 & 627 & 11695 \\
\hline $\begin{array}{r}\text { Estimated Util } \\
\text { Electric Cooling Use }\end{array}$ & $\mathrm{kWh}$ & \multicolumn{3}{|c|}{$\begin{array}{c}\text { Estimated Limited } \\
\text { Cooling }\end{array}$} & 442 & 567 & 689 & 857 & 1349 & 551 & 260 & $\begin{array}{c}\text { Est. Limited } \\
\text { Cooling }\end{array}$ & 4715 \\
\hline
\end{tabular}

\section{Step 7: Determine Target Simulated Heating and Cooling Energy Use for Each Fuel}

This step is primarily a time-saving step for the modeling process. In the end, we matched the simulated heating and cooling energy use to the utility data the way we have done with the base load (Table 8) by applying weather correction Ratio B (AMY/ TMY3) to the simulated heating and cooling energy use. However, before getting to that step, many revisions to the simulation model were required. Rather than going through the post-processing step over and over, the total process time was shortened significantly by determining what simulation output would create a perfect match. These "target" values allowed modelers to quickly (visually) assess if the output from each modification was moving the model closer or further away from the desired balance of heating and cooling energy use. The targets are created by applying Ratio A to the estimated utility bill heating and cooling energy use. Ratio A is the inverse ratio of Ratio $\mathrm{B}$, therefore, once the desired output is achieved, it will convert into the desired weather corrected simulation result by application of Ratio B. The target heating and cooling energy use for the Riverdale house are shown in Table 10. 
Table 10. Target Model Output for Gas Heating and Electric Cooling Energy Use

\begin{tabular}{|c|c|c|c|c|c|c|c|c|c|c|c|c|c|c|}
\hline & Units & Jan & Feb & March & April & May & June & July & Aug & Sept & Oct & Nov & Dec & Annual \\
\hline $\begin{array}{r}\text { Estimated Util Gas } \\
\text { Heating Use }\end{array}$ & Therms & 35.3 & 31.3 & 23.3 & \multirow{3}{*}{\multicolumn{7}{|c|}{ Estimated Limited Heating }} & 36.3 & 37.3 & 163.5 \\
\hline HDD Ratio A & & 1.39 & 1.28 & 1.74 & & & & & & & & 1.74 & 1.74 & \\
\hline $\begin{array}{r}\text { Target Simulation } \\
\text { Gas Heating Use } \\
\end{array}$ & Therms & 49.16 & 40.07 & 40.64 & & & & & & & & 63.31 & 65.06 & 258.24 \\
\hline $\begin{array}{r}\text { Estimated Util } \\
\text { Electric Cooling Use }\end{array}$ & $\mathrm{kWh}$ & \multirow{3}{*}{\multicolumn{3}{|c|}{$\begin{array}{l}\text { Estimated Limited } \\
\text { Cooling }\end{array}$}} & 442 & 567 & 689 & 857 & 1349 & 551 & 260 & \multirow{3}{*}{\multicolumn{2}{|c|}{$\begin{array}{l}\text { Est. Limited } \\
\text { Cooling }\end{array}$}} & 4715 \\
\hline CDD Ratio A & & & & & 0.55 & 0.82 & 0.96 & 0.98 & 0.80 & 0.76 & 0.94 & & & \\
\hline $\begin{array}{r}\text { Target Simulation } \\
\text { Elec Cooling Use }\end{array}$ & KWh & & & & 244 & 465 & 664 & 836 & 1085 & 418 & 243 & & & 3955 \\
\hline
\end{tabular}

\section{Step 8: Modify Occupancy and Operational Characteristics in Model}

Based on homeowner input, we adjusted parameters related to heating and cooling loads and equipment. It is worth noting that none of the occupancy or operation adjustments influence the HERS Index calculation. The software applies the HERS settings and schedules to the file at the time of calculation. The major adjustments related to homeowner input included:

- Restriction of heating and cooling system operation to the defined seasons

- Thermostat set points (71 for cooling and 79 for heating!)

Additional adjustments were made to increase and decrease heat gain and loss, such as altering window blind and screen status. Though not applicable to this house, the number of bedrooms could have been adjusted to reflect higher or lower occupancy (bedrooms plus one) without affecting the base load.

We conducted a series of modifications, comparing heating and cooling output to targets after each change. As shown in Table 11 in the next section, the best match brought annual gas heating energy use to 185 therms, $40 \%$ lower than the target of 258 and electricity cooling use to $4,052 \mathrm{kWh}, 2 \%$ higher than the target of 3,955 .

\section{Step 9: Modify Simulated Heating and Cooling Energy Use and Combine with Simulated Base Energy Use}

Researchers applied Ratio B (Table 7) to the heating and cooling energy use from the trued-up model to ameliorate weather differences between model and utility data (Table 11). These were combined with the simulated base energy use in Table 8 to arrive at a trued-up simulated whole-house energy use shown in Table 12. 
Table 11. Monthly and Annual Heating and Cooling Energy Use

\begin{tabular}{|c|c|c|c|c|c|c|c|c|c|c|c|c|c|c|}
\hline & Units & Jan & Feb & Mar & Apr & May & June & July & Aug & Sept & Oct & Nov & Dec & Total \\
\hline \multicolumn{15}{|c|}{ Heating Monthly Gas Use } \\
\hline HERS Index Model & therms & 41 & 29 & 15 & & & & & & & & 12 & 35 & 132 \\
\hline Utility (Estimated) & therms & 35 & 31 & 23 & & & & & & & & 36 & 37 & 164 \\
\hline Trued Up Model & therms & 51 & 41 & 30 & & & & & & & & 20 & 43 & 185 \\
\hline $\begin{array}{l}\text { Trued Up Model with } \\
\text { AMY/TMY3 HDD } \\
\text { correction (Ratio B) }\end{array}$ & therms & 36.6 & 32.0 & 17.2 & & & & & & & & 19.73 & 42.78 & 148 \\
\hline \multicolumn{15}{|c|}{ Cooling Monthly Energy Use } \\
\hline HERS Index Model & kWh & & & & 267 & 767 & 1430 & 1505 & 1593 & 1065 & 528 & & & 7155 \\
\hline Utility (Estimated) & kWh & & & & 442 & 567 & 689 & 857 & 1349 & 551 & 260 & & & 4715 \\
\hline Trued Up Model & kWh & & & & 256 & 460 & 714 & 764 & 817 & 615 & 426 & & & 4052 \\
\hline $\begin{array}{l}\text { Trued Up Model with } \\
\text { AMY/TMY3 HDD } \\
\text { correction (Ratio B) }\end{array}$ & kWh & & & & 464 & 561 & 741 & 783 & 1016 & 811 & 455 & & & 4831 \\
\hline Measured Cooling & kWh & & & & & & & 1137 & 1153 & 775 & 418 & & & \\
\hline
\end{tabular}

Table 12. Monthly and Annual Total Energy Use

\begin{tabular}{|c|c|c|c|c|c|c|c|c|c|c|c|c|c|c|}
\hline & Units & Jan & Feb & Mar & Apr & May & June & July & Aug & Sept & Oct & Nov & Dec & Total \\
\hline \multicolumn{15}{|l|}{ Total Monthly Gas Use } \\
\hline HERS Index Model & therms & 66 & 51 & 39 & 22 & 21 & 20 & 19 & 19 & 20 & 21 & 34 & 59 & 391 \\
\hline Utility & therms & 43 & 39 & 31 & 11 & 10 & 5 & 8 & 12 & 10 & 12 & 44 & 45 & 270 \\
\hline Trued Up Model & therms & 60 & 49 & 39 & 10 & 10 & 9 & 9 & 9 & 9 & 10 & 29 & 53 & 296 \\
\hline $\begin{array}{l}\text { Trued Up Model with } \\
\text { AMY/TMY3 HDD } \\
\text { correction (Ratio B) }\end{array}$ & therms & 46 & 40 & 26 & 10 & 10 & 9 & 9 & 9 & 9 & 10 & 29 & 53 & 259 \\
\hline \multicolumn{15}{|c|}{ Total Monthly Electric Use } \\
\hline HERS Index Model & kwh & 395 & 383 & 475 & 648 & 1158 & 1809 & 1896 & 1984 & 1444 & 920 & 534 & 402 & 12,048 \\
\hline Utility & kwh & 514 & 541 & 714 & 1003 & 1128 & 1250 & 1418 & 1910 & 1112 & 821 & 657 & 627 & 11,695 \\
\hline Trued Up Model & kWh & 524 & 471 & 512 & 818 & 1040 & 1276 & 1344 & 1397 & 1177 & 1006 & 491 & 519 & 10,575 \\
\hline $\begin{array}{l}\text { Trued Up Model with } \\
\text { AMY/TMY3 HDD } \\
\text { correction (Ratio B) }\end{array}$ & kWh & 524 & 471 & 512 & 1026 & 1141 & 1303 & 1363 & 1596 & 1373 & 1035 & 491 & 519 & 11,354 \\
\hline Monitored Cooling & kwh & & & & & & & 1724 & 1755 & 1304 & 915 & & & \\
\hline
\end{tabular}

\section{Step 10: Compare Trued-Up Model Whole-House Use to Post-retrofit Utility Bills}

The simulated whole house energy use, which has been corrected for weather, can now be compared to actual utility bills for that period to assess the accuracy of the true-up procedure for this home. Figures 3 and 4 show the monthly combined heating, cooling, and base energy uses for the three models (HERS Index, trued-up, and weather corrected) and the post-retrofit utility bills, for gas and electric use respectively. Figures 5 and 6 show the annual projected and utility bill energy use for each fuel. It is apparent in all four figures that the trued-up models with weather corrections (green) more closely approximate the utility data (blue) than the other two models. 


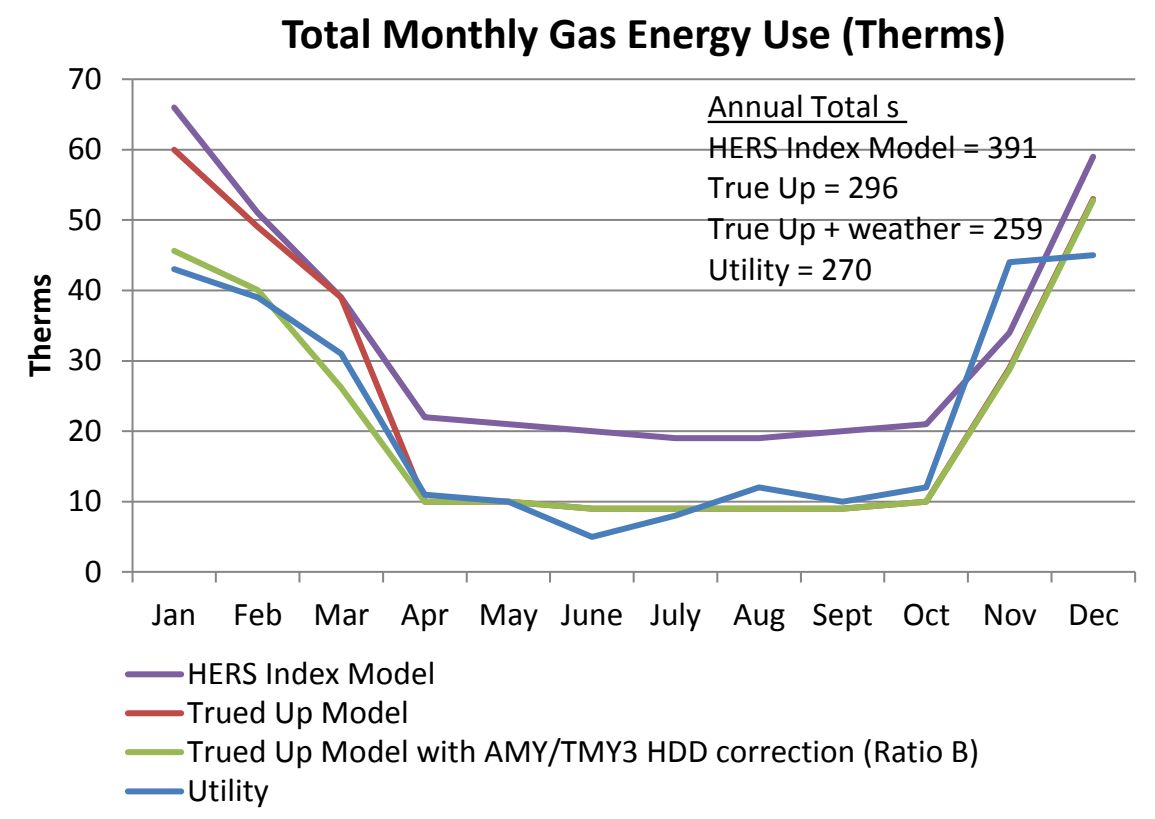

Note: The red line is behind the green line in November and December.

\section{Total Monthly Electric Energy Use (kWh)}

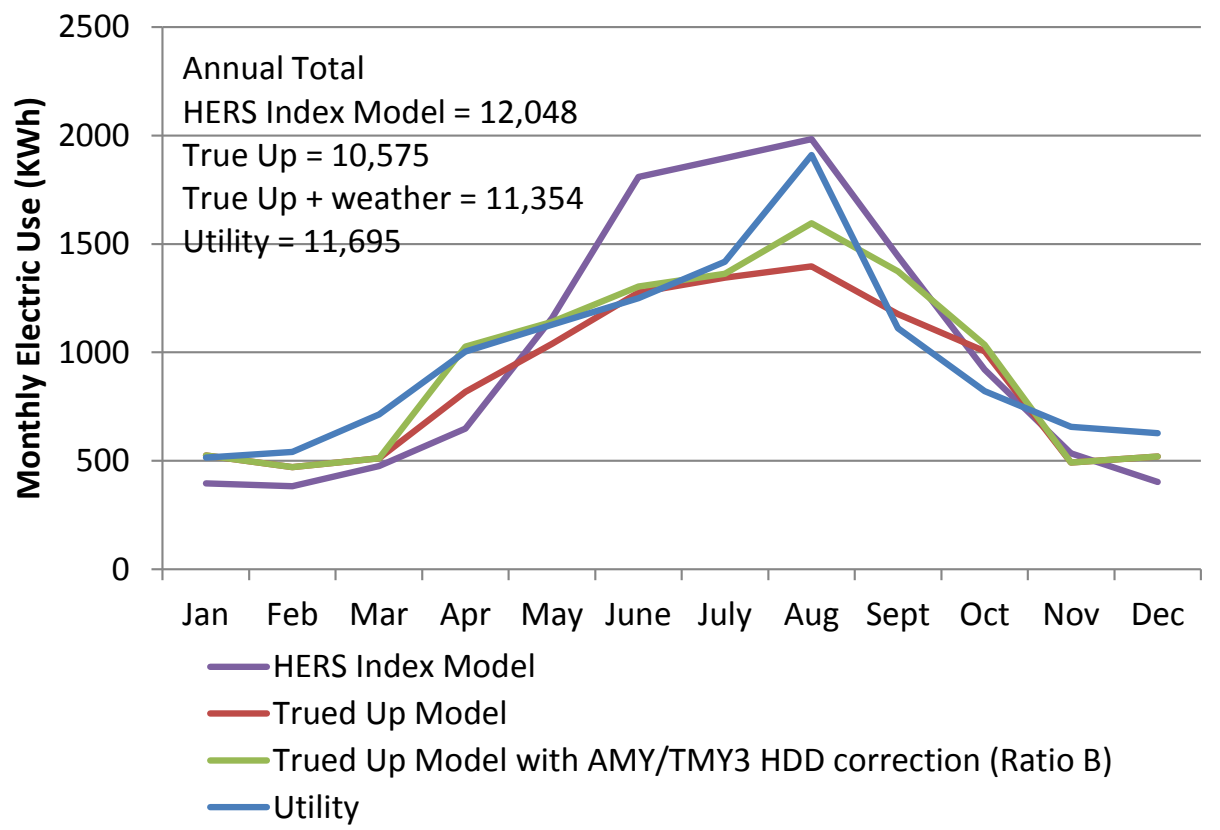

Figures 3 and 4. Total Monthly Gas (top) and Electric (bottom) Energy Use from the HERS Index Model, Trued-up Model, Weather Corrected Trued-up Model Output and Utility Bills. 

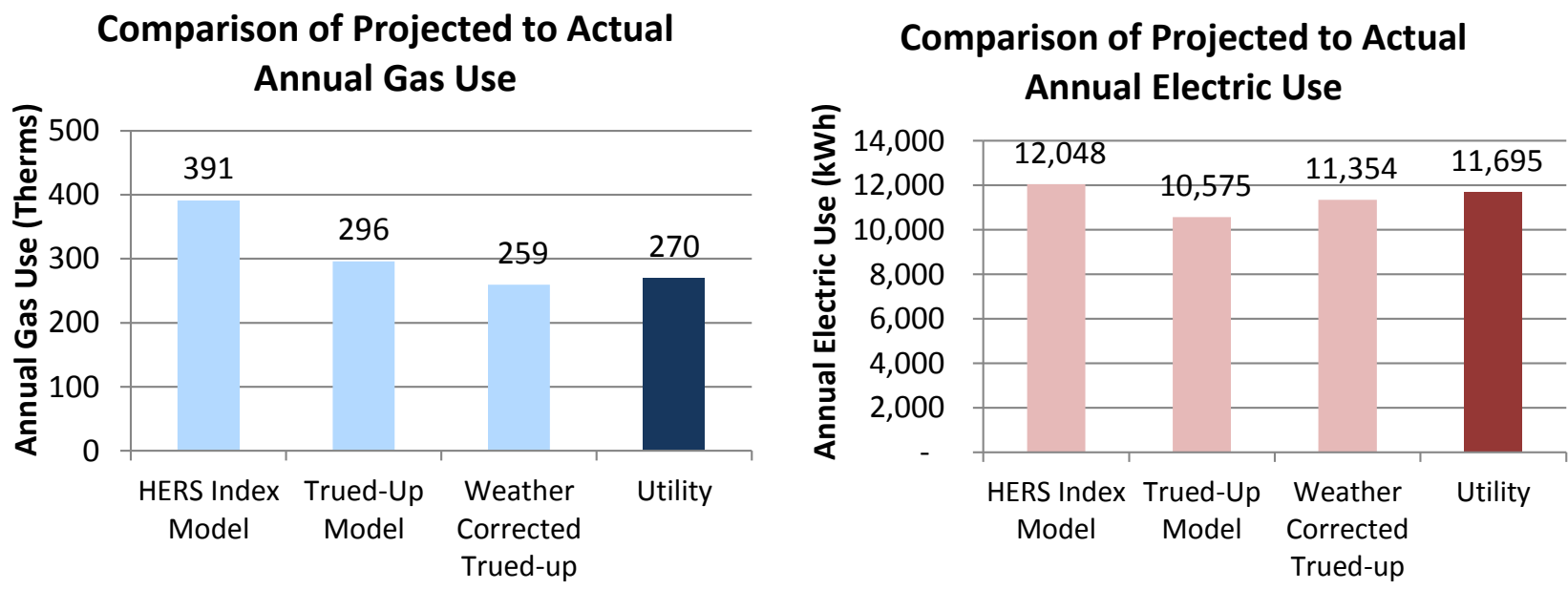

Figures 5 and 6. Total Annual Gas and Electricity Projections and Utility Bills

\section{Step 11: Modify the Trued-Up Model to Reflect Pre-Retrofit Characteristics}

Based on the pre-retrofit audit and HERS rating model, researchers changed the equipment and envelope characteristics outlined in Table 5 in the trued-up model to represent pre-retrofit conditions. We were careful not to modify any parameters related to occupancy or operational conditions since those would be unknown for an unoccupied house and are assumed to be similar to the post-retrofit period. Pre-retrofit model output was modified by Ratio B in the same manner as the post-retrofit model output. The comparison of the two trued-up models shows 37\% total electric savings and $36 \%$ gas savings. Heating and cooling savings were $43 \%$ and $58 \%$, respectively (Table 13). Initially, this study estimated energy savings based on the HERS Indexes for this home at 43\%; whereas the true up procedure produced slightly lower estimated savings.

Table 13. Trued-Up Simulation Data with Weather Correction (Ratio B)

\begin{tabular}{|l|c|c|c|c|}
\hline & Unit & Post Model & Pre Model & $\begin{array}{c}\text { Pre-Post } \\
\text { Savings }\end{array}$ \\
\hline Annual Total Gas & therms & 259 & 406 & $36 \%$ \\
\hline Annual Total Electric & $\mathrm{kWh}$ & 11,354 & 17,941 & $37 \%$ \\
\hline Annual Heating & therms & 148 & 260 & $43 \%$ \\
\hline Annual Cooling & $\mathrm{kWh}$ & 4,831 & 11,522 & $58 \%$ \\
\hline
\end{tabular}

\section{Conclusions \& Recommendations}

Although it is difficult to gauge energy savings directly in retrofits for which pre-retrofit occupancy and related energy consumption are unknown, whole-house improvement due to retrofit measures can be estimated using a standardized procedure that holds all factors other than building characteristics equal. The procedure presented here produces savings estimates with particular relevance to the current occupants and climate conditions, which improves the accuracy of the estimate over a direct comparison of HERS Indexes that does not account for these confounding factors. However, this more accurate 
procedure takes additional tenacity and time to complete. Even when we have the benefit of direct measurement, shifting lifestyle patterns from one year to the next can obscure even large improvements in whole-house efficiency by a change in the number of occupants, time spent at home, extensive vacations, unexpected long-term guests, etc. Earlier discussion of utility bill comparisons revealed estimated cooling savings of about $40 \%$, a difference of $18 \%$ from the true-up exercise. In contrast, the apparent whole-house savings were unexpectedly low, just $5 \%$ based on comparison of actual utility bills for the home used in this analysis. With investigation, we might find the reason for these discrepancies.

In the interest of pursuing a true-up procedure using home energy rating models, such as EG USA, as a starting point, developing macro-enabled spreadsheets or other automated post-processing procedures could significantly improve total modeling time and make true-up procedures more practical. It may be beneficial to open discussions with HERS rating software companies to allow for and automate this type of flexibility. Retrofit activity appears to be gaining market share, and this type of true up procedure would be a potentially valuable capability with relevance to marketing, program management, and retrofit success metrics. 


\section{References}

Blanchard, J; E Giver, S Widder, and M Baechler. 2012. "Actual and Estimated Energy Savings Comparison for Deep Energy Retrofits in the Pacific Northwest." [DRAFT]. Pacific Northwest National Laboratory, Richland, WA.

Chandra, S; S Widder; G Parker; S Sande; J Blanchard; D Stroer; J McIlvaine; D Chasar; D Beal; and K Sutherland. 2012. "Pilot Residential Deep Energy Retrofits and the PNNL Lab Homes." PNNL-21116, Pacific Northwest National Laboratory, Richland, WA.

Jackson R, EJ Kim, and S Roberts. 2011. Advancing Residential Retrofits in Atlanta. Draft report, Oak Ridge National Laboratory, Oak Ridge, Tennessee.

McIlvaine, J; D Chasar; D Beal; K Sutherland; D Parker; and K Abbot. 2012. "Partnership for High Performance Housing." FSEC-CR-1911-12. Florida Solar Energy Center, Cocoa, Florida. Available at: http://www.fsec.ucf.edu/en/publications/pdf/FSEC-CR-1911-12.pdf

Residential Energy Services Network (RESNET). 2006. “2006 Mortgage Industry National Home Energy Rating Systems Standards.” Residential Energy Services Network, Inc. Oceanside, California. Available at: http://www.resnet.us/standards 




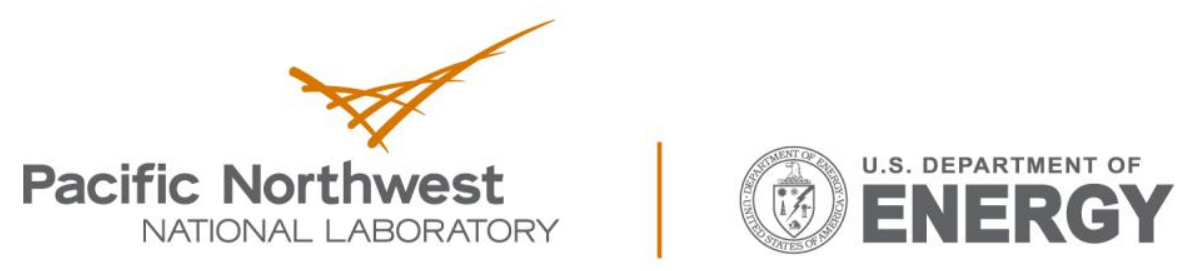

Proudly Operated by Battelle Since 1965

902 Battelle Boulevard

P.O. Box 999

Richland, WA 99352

1-888-375-PNNL (7665)

www.pnnl.gov 